\title{
The Impact of Firm and Entrepreneurial Characteristics on Access to Debt Finance by SMEs in King Williams' Town, South Africa
}

\author{
Olawale Fatoki (Corresponding author) \\ Department of Business Management, University of Fort Hare \\ Alice, P.B. X1314, Eastern Cape 5700, South Africa \\ Tel: 927-40-653-2248 E-mail: ofatoki@ufh.ac.za \\ Francis Asah \\ Department of Business Management, University of Fort Hare \\ Alice, P.B. X1314, Eastern Cape 5700, South Africa \\ E-mail: asfrant03@yahoo.com
}

Received: February 21, $2011 \quad$ Accepted: March 23, $2011 \quad$ doi:10.5539/ijbm.v6n8p170

\begin{abstract}
SMEs contribute positively to economic growth, employment and poverty alleviation in South Africa. However, the failure rate of SMEs is very high in South Africa. One of the factors limiting the survival and growth of SMEs in South Africa is non-availability of debt financing. This study investigates the impact of firm and entrepreneurial characteristics on access to debt finance by SMEs in South Africa. Data was collected through self-administered questionnaire in a survey. The statistical analyses included descriptive statistics, Pearson correlation and logistic regression. The results indicate that firm and entrepreneurial characteristics impact on access to debt finance by SMEs. The study recommends that SMEs owners/managers should be investment ready by providing collateral, attend seminars and training programs to improve on their managerial competence.
\end{abstract}

Keywords: Firm and entrepreneurial characteristics, Debt finance, SMEs

\section{Introduction}

According to Abor and Quartey (2010:218) SMEs are of great socio-economic significance. However, their long-term growth and competitiveness has been compromised by the chronic and often acute constraints on their access to formal-sector finance, among other systemic and institutional problems in developing countries. In South Africa, SMEs have been identified by the government as a priority in increasing jobs so as to reduce the high unemployment rate which is currently estimated at 25.5\% (Statistics South Africa, 2010). The failure rate of SMEs (especially new ones) is very high. $75 \%$ of new SMEs created in South Africa fail within the first two years of operation. FinMark Trust (2006) stipulates that various challenges and impediments cause the high failure rate of SMEs in South Africa. One of the primary causes of SME failure is non-availability of external finance (Beck, 2007:405). This is termed the "finance gap". Pretorius and Shaw (2004:223) observe that access to external finance is needed to reduce the impact of cash flow problems for SMEs. Financing is needed for SMEs to start and expand operations, develop new products, invest in new staff or production facilities. A vast majority of SMEs depend on internal finance (contribution from the owners, family and friends). Internal finance is often in adequate for SMEs to survive and grow. A large percentage of SME failure is attributed to inadequate capital structure or resource poverty.

According to Demirguc-Kunt, Maksimovic, Beck and Laeven (2006:933) the two primary sources of external finance for SMEs are equity and debt. External equity in the form of venture capital or the stock exchange is usually not available for SMEs (Shane, 2008). Research by Berry et al. (2002), documents the reliance of SMEs on bank debt as a source of financing. However, access to bank debt is, paradoxically, a frequently cited challenge for SMEs. According to Smorfitt (2009) SMEs in South Africa do struggle to raise finance from banks. Stiglitz and Weiss (1981:395) refer to this phenomenon as capital rationing. Majed, Alsharayri and Dandan (2010) and Sorooshian, Norzima, Yusuf and Rosnah (2010) point out that the factors that can impact on the capital structure and performance of SMEs include firm characteristics and entrepreneurial characteristics. Firm characteristics are traits or features specific to the firm which can affect positively or negatively the performance of the firm. Firm characteristics include factors such as the age of the firm, the size of the firm and the availability of collateral and business information. Entrepreneurial characteristics are those traits or attributes that are specific to the owner of the firm which can impact on the performance of the firm negatively or positively. Entrepreneurial characteristics include the managerial competency of the owner of the firm, 
networking and gender. A Meta analysis of the literature on entrepreneurial finance revealed that no study has investigated empirically the impact of firm and entrepreneurial characteristics on access to debt finance by SMEs in South Africa. This study seeks to fill the gaps in the literature.

\section{Objective of the study}

SMEs are the engine of sustained economic expansion in both developed and emerging economies. One critical success factor for entrepreneurial SMEs is gaining sufficient access to external sources of finance (Le, Venkatesh \& Nguyen, 2006: 211). The main objective of the study is to investigate empirically the impact of firm and entrepreneurial characteristics on access to finance by SMEs in South Africa.

\section{Literature}

\subsection{Theoretical Construct}

Capital structure is described as the mix of debt and equity that a firm uses to finance its operations (Gitman, 2003). The theoretical principles underlying capital structure can generally be described in terms of the static trade-off theory by Modigliani and Miller $(1958,1963)$ the agency theory by Jensen \& Meckling (1976) and extended by Stiglitz and Weiss (1981) and the pecking order theory by Myers (1984). Modigliani and Miller (1963) argue that because the interest on debt is tax-deductible, thereby creating tax savings for the borrower, it becomes possible for firms to minimize their costs of capital and maximize shareholders' wealth by using debt. The tax advantage of debt makes it cheaper than equity. The mix of cheap debt with relatively expensive equity reduces a firm's cost of capital, which is the cut-off rate for investment acceptance decisions. This is known as the leverage effect of debt. According to Miller and Modigliani (1963) a firm should have $100 \%$ debt in its capital structure. This way the firm can take absolute advantage of the tax-shield. Scott (1972) and Kraus and Litzenberger (1973) point out that theoretically $100 \%$ tax shield does not exist in reality because of distress costs. Debt leads to a legal obligation to pay interests and principal. If a firm cannot meet its debt obligations it is forced into bankruptcy and incurs associated costs.

The agency theory of Jensen and Meckling (1976: 306) was based on the conflicts between the shareholders and managers of the firm and the equity holders and debt holders. Conflicts between shareholders and managers arise because managers do not hold total residual claim thus they cannot capture the entire gain from their value-maximizing activities. On the other hand, conflict arises between debt holders and equity holders because debt contracts give equity holders an incentive to invest sub-optimally. The debt contract results in asymmetric distribution of the gains. According to Stiglitz and Weiss (1981: 394) agency problems such as asymmetric information and moral hazards can impact on the accessibility of credit and hence the capital structure of SMEs.

Myers (1984) alludes in the pecking order theory that there is no well-defined optimal capital structure; instead the debt ratio is the result of hierarchical financing over time. Management has a preference to choose internal financing before external financing. When a firm is forced to use external financing sources, managers select the least risky and demanding source first. When it is necessary to issue external sources, debt issuance is preferred to new equity. The pecking order theory suggests the use of external debt before the use of external equity by SMEs. Frelinghaus, Mostert \& Firer, 2005:9) point out that despite the disadvantages of debt (financial distress), the inadequacy of internal equity and the non-availability of external equity imply that debt is one of the principal sources of finance for SMEs.

\subsection{Empirical Review}

\subsubsection{Firm Characteristics}

Age

According to Chandler (2009:10) the longer a firm exists and the bigger it is, the more it signals that it can weather tough economic conditions. Furthermore, by staying in business, a firm can signal that it does not adopt opportunistic behaviour. According to Klapper (2010:605), younger firms (less than 4 years) rely less on bank financing and more on informal financing. This view is also supported by Ngoc et al. (2009:868) which find that it is often difficult and expensive for young SMEs to access bank financing, due in large part to information asymmetry between the banks and firms. Bougheas, Mizen and Yalcin (2005:218) point out that young firms are more failure prone than older ones. Therefore, it is hypothesized that, there is a positive relationship between the age of the firm and access to debt finance from commercial banks.

Size

Burkart and Ellingsen (2004:589) state that the size of a firm has an important influence on the debt ratios as firms with more real assets tends to have greater access to long-term debt. Honhyan (2009) finds that larger firms tend to be more diversified and fail less often, so size can be an inverse proxy for the probability of bankruptcy. Cassar (2004) argues that it may be relatively more costly for smaller firms to resolve information asymmetries with debt providers. Consequently, smaller firms may be offered less debt capital. In addition, transaction costs are typically a function of scale and may be higher for smaller firms. Therefore, it is hypothesized that, there is a positive relationship between the size of the SME and access to debt finance from commercial banks. 
Bougheas et al. (2005:214) contend that collateral is an important factor for SMEs in order to access debt finance. Collateral reduces the riskiness of a loan by giving the financial institution a claim on a tangible asset without diminishing its claim on the outstanding debt. Coco (2000:192) point out that collateral is the lender's second line of defence. Thus, collateral can solve problems derived from asymmetries in valuation of projects, uncertainty about the quality of projects and the riskiness of borrowers, and problems related to the cost of monitoring or supervising borrowers' behaviour. Collateral requirements also reduce moral hazard problems. Barbosa and Moraes (2004) argue that SMEs owners/entrepreneur that invest heavily in tangible assets tend to have higher financial leverage since they can borrow at lower interest rates if their debt is secured with such assets. As a result, it is hypothesised that there is a positive relationship between collateral and access to debt finance by SMEs from commercial banks.

\section{Business information}

According to Kitindi, Magembe and Sethibe (2007:55) creditors, banks and other lenders use financial information provided by firms to analyse their present performance and predict future performance. Information obtained from the financial statements acts as indicator of borrower's future prospects and ability to service a loan. Pretorius and Shaw (2004:225) contend that a good business plan is perceived as one of the most essential documents to be prepared by the SME. Sarapaivanich and Kotey (2006:221) point out that the lack of adequate information leads to information asymmetry and credit rationing. Therefore, it is hypothesized that there is a positive relationship between business information and access to debt finance by SMEs from commercial banks.

\section{Location and insurance}

Berger and Udell (2002) find that the effects that the geographic proximity to banks and customers has a relationship on a firm's use of leverage. Banks that are geographically closer to their customer firms are better able to use soft qualitative information about their customers' credit quality. Geographical proximity to either critical buyers or suppliers produces a form of enhanced environmental scanning that enables SMEs to more easily identify and exploit growth opportunities in the market. Gilbert (2008) points out that the geographical area where the firm is launched has implications for its access to markets and resources. Firms located in metropolitan areas may therefore have higher chance of success than those located in rural areas. The South African Presidency (2008) finds that firms that are looked in the urban areas are more likely to succeed than firms that are in the rural areas due to the high crime rate. Given the high crime rate in South Africa, insurance is very important. The United Nations Human Settlement Programme (2002) points out that South Africa has the dubious distinction of being amongst the world's five most-murderous nations. According to the South African Police Service Crime Statistics (2009) while the incidences of virtually all major categories of crime has fallen during the past year, business related crime is on the increase. Chidokufa (2009) finds that less than half of all South African SMEs surveyed did not have any insurance cover in the event of a crime. Consequently, it is hypothesised that location and insurance positively impacts on access to debt finance.

\section{Industry}

Myers (1984) as cited in Hall, Hutchinson and Michaelas (2000) suggests that the industry in which a firm operates does not directly determine its capital structure but may do so indirectly via the nature and composition of the firm's assets. Barbosa and Moraes (2004) point out that the relationship between industry classification and financial leverage are based on the assumption that industry classification is a proxy for business risk. The rationale for this may be that firms in the same industry face the same environmental and economic conditions and, therefore, tend to cluster with respect to variance of earnings and sales. Hall et al. (2000) conclude however that firm specific characteristics are more important than structural characteristics of industry and financial and strategy variables have far greater explanatory power than industry specific effects.Abor (2007) finds that SMEs in the agricultural sector exhibit the highest capital structure and asset structure or collateral value, while the wholesale and retail trade industry has the lowest debt ratio and asset structure. Therefore, it is hypothesised that industry positively impacts on access to debt finance.

\section{Incorporation}

Cassar (2004) notes that banks may perceive incorporation as a good signal that portrays credibility and formality of operations. Abor (2008) point out that the form of business could affect the debt-equity decisions of SMEs. Shareholders of corporations and limited companies have limited liability against losses, whereas general partners and owners of sole proprietorships have unlimited liability. Consequently, shareholder-creditor conflicts are more likely among corporations and limited companies than they are for general partners and sole proprietorships. Thus, corporations and limited liability companies may be more likely to finance their projects with equity, while sole proprietors are more likely to employ debt financing. Coleman and Cohn (2000) however find evidence suggesting a positive relationship between leverage and incorporation. It is hypothesised that incorporation positively impacts on access to credit by SMEs.

\subsubsection{Entrepreneurial Characteristics}

\section{Managerial competency}


According to Hisrich and Drnovsek (2002:172) managerial competencies as measured by education, managerial experience, start-up experience and knowledge of the business positively impact on the performance of SMEs. Martin and Staines (2008) examine the importance of management competence in SMEs success. They found out that, lack of managerial experience, skills and personal qualities are found as the main reasons why SMEs fail. In South Africa, Herrington and Wood (2003) points out that lack of education and training has reduced management capability in SMEs in South Africa and account for one of the reasons for their high failure rates. Smit and Smit (2007:5) agree that South Africa has a critical shortage of skilled managers. Therefore, it is hypothesised that there is a positive relationship between managerial competency and access to debt finance by SMEs from commercial banks.

\section{Networking and relationship with bank}

Coulthard and Loos (2007) describe networking in a small firm context as an activity in which entrepreneurially oriented SME owners build and manage personal relationships with particular individuals in their surroundings. Networking is seen as a means of raising required capital, identifying market opportunities, obtaining personnel, identifying suppliers, identifying and developing technology. According to Owualah (2002:90) long-standing relationship between a bank and SMEs owners does convey an advantage in the case of bank credit. Korkeamaki and Rurherford (2006) find however that SMEs with a close banking relationship use less debt in their financing. Networking could be expected to provide to the banks, trade creditors, venture capitalists and financial institutions information on legitimacy, which in turn should give the SMEs advantages in accessing debt finance (Ngoc, le \& Nguyen. 2009:120). Consequently, it is hypothesised that networking and long relationship with banks positively impact on access to debt finance by SMEs.

\section{Gender}

Abor (2008) notes that the gender of the small business owner may affect the capital structure choice of the firm. Abor (2008) argues that women-owned businesses are less likely to use debt for a variety of reasons, including discrimination and greater risk aversion. Freel, Carter, Tagg and Mason (2010) find that twice as many businesses were discouraged from applying for a bank loan than had their loan request denied in the United Kingdom Watson, Newby and Mahuka (2009) conclude that there is also no evidence that Australian SME owners (particularly female owners) are being discouraged from applying for loans from a financial institution because they believe their application will be rejected. The results suggest that other demand-side issues (particularly risk-taking propensity and desire to maintain control) play a more important role in the capital structure decision making of SME owners. Mijid (2009) finds that in the United States of America women owned firms have higher loan denial rates and lower application rates than their male counterparts. In contrast, Coleman (2000) finds that there are no significant differences in the usage of debt between men and women, and gender is not a significant predictor of financial leverage. Thus, it is hypothesised that gender does not impact on access to debt finance by SMEs.

\section{Research methodology}

The empirical study focused on King William's Town in the Eastern Cape Province of South Africa. Data was collected through a survey using self-administered questionnaire in a survey. The questionnaire comprised of both close-ended and open-ended questions. The study focused on SMEs which are registered with the Enterprise Directory and the Yellow Pages telephone directory. The population of SMEs was 173. Raosoft sample size calculator was used to calculate the sample size. Raosoft sample size calculator is statistical software that enables researchers to determine the sample size given the following variables: The margin of error, The confidence level, the population and the expected response distribution (Raosoft, 2010). Raosoft provided a minimum recommended sample size of 120 . However, 150 questionnaires were distributed because of the limitations associated with self-administered data collection method such as non-response. Data analysis was done using the Statistical Package for Social Sciences (SPSS). Pre-testing the research instrument was done through a pilot study covering 20 respondents. The process of pre-testing helped the researcher to identify areas where the questionnaire needed corrections. Statistical analysis includes descriptive statistics, Pearson correlation and logistic regression. Validity and reliability were ensured by using a statistician and a panel of experts to evaluate the research instrument for conceptual clarity, pre-testing the research instrument in a pilot study and comprehensively reviewing the literature for theoretical constructs and empirical conclusions. Case wise deletion method was used to treat missing values. The Kolmogorov-Smirnov test was used to determine the normality of the data.

\section{Results and discussions}

\subsection{Demographics}

One hundred and fifty questionnaires were distributed and one hundred and seven returned. The response rate was $71 \%$. $68 \%$ of the respondents were males and $32 \%$ females. The results indicate that SMEs owners /managers in the study area are predominantly within the age bracket of (31-40). Out of the one hundred and seven that returned the questionnaires, $91 \%$ of the respondents needed external finance, indicating that there is a high demand for credit by SMEs from commercial banks. $40 \%$ of the respondents needed external finance to 
invest in working capital, $57 \%$ in fixed asset and 3\% in business acquisition. Only 39\% of the respondents were successful in their application, indicating a high rejection rate of credit applications by the banks.

\section{Pearson correlation and logistic regression results for firm characteristics and access to debt finance}

\section{Insert Tables 1 and 2 here}

For collateral, the Pearson correlation results are: personal property $(\mathrm{r}=0.957$, $\mathrm{p}$-value $=0.01)$ and business property $(\mathrm{r}=0.824$, $\mathrm{p}$-value 0.03 ). The odd ratio for personal property is 7.14 with a $\mathrm{p}$-value of 0.03 and the odd ratio for business property is 6.26 with a p-value of 0.01 . The results of the Pearson correlation indicate that there is a significant positive relationship between the collateral and access to debt finance by SMEs. The results of the logistic regression indicate that SMEs with collateral (personal or business property) are significantly more likely to be successful in their credit applications compared to SMEs without collateral. In addition, insurance is a significant factor.

The Pearson correlation results for business information are: business plan $(r=0.834$, $p$-value $=0.04)$ and financial information $(\mathrm{r}=0.627, \mathrm{p}$-value $=0.01)$. The odd ratio for business plan is 6.81 with a $\mathrm{p}$-value of 0.01 and the odd ratio for financial information is 6.11 with a p-value of 0.03 . The results of the Pearson correlation indicate that there is a significant positive relationship between business information and access to debt finance by SMEs. The logistic regression more confirms these results.

With respect to the age of the firm, the Pearson correlation results are: for firms between 1-4 years $(\mathrm{r}=0.293$, $\mathrm{p}$-value $=0.12), 5-9$ years $(\mathrm{r}=0.557, \mathrm{p}$-value $=0.01), 10-14$ years $(\mathrm{r}=0.59, \mathrm{p}$-value $=0.03)$, and firms that are 15 years and above $(\mathrm{r}=0.681, \mathrm{p}$-value $=0.02)$. The odd ratio for firms between $5-9$ years is 5.36 with a $\mathrm{p}$-value of 0.04 , the odd ratio for firms between 10-14 years is 5.88 with a p-value of 0.02 and the odd ratio for firms from 15 years and above is 0.681 with a p-value of 0.02 . The results of the Pearson correlation indicate that there is no significant relationship between firms that are between 1-4 years and access to debt finance by SMEs. The results of the Pearson correlation also indicate that there is a significant positive relationship between firms that are older than five years and access to debt finance by SMEs. With firms between 1-4 years as the reference, the logistic regression also confirms these results. The results of the logistic regression indicate that SMEs that are more than five years old are significantly more likely to be successful in their credit application compared to SMEs that are less than five years old.

For the firm size, the Pearson correlation results are: firms with 1-49 employees $(r=0.252$, $p$-value $=0.29), 50-99$ employees $(\mathrm{r}=0.497$, $\mathrm{p}$-value $=0.02), 100-149$ employees $(\mathrm{r}=0.643$, $\mathrm{p}$-value $=0.04)$, and firms that have between $150-200$ employees $(\mathrm{r}=0.776$, $\mathrm{p}$-value $=0.01)$. The odd ratio for firms that have between $50-99$ employees is 3.30 with a p-value of 0.03, the odd ratio for SMEs with 100-149 employees is 4.42 with a p-value of 0.01 and the odd ratio for firms' with150-200 employees is 4.59 with a p-value of 0.01 . The results of the Pearson correlation indicate that there is no significant relationship between SMEs that have less than 50 employees (1-49 employees) and access to debt finance. The results of the Pearson correlation also indicate that there is a significant positive relationship for SMEs that have more than 50 employees and access to debt finance. With SMEs that have less than 50 employees (1-49 employees) as the reference, the logistic regression also confirms these results. The results of the logistic regression indicate that SMEs that have more than 50 employees are significantly more likely to be successful in their credit application compared to SMEs that have less than 50 employees.

The Pearson correlation results for location are: urban $(r=0.764$, $p$-value $=0.03)$ and rural $(r=0.217$, $p$-value $=0.29$ ). The odd ratio for firms located in the urban areas is 6.81 with a p-value of 0.02 and 1.26 with a p-value of 0.34 . The results of the Pearson correlation indicate that there is a significant positive relationship between SMEs that are located in the urban areas and access to debt finance. The logistic regression also confirms these results. The results of the logistic regression indicate that SMEs that are located in the towns and cities are significantly more likely to be successful in their credit application compared to SMEs located in rural areas. The Pearson correlation result for industry is 0.197 with a p-value of 0.37 . The odd ratio for industry is 2.71 with a $\mathrm{p}$-value of 0.23 . The results indicate that there is no significant relationship between the industry (line of business) and access to debt finance.

\section{Pearson correlation and logistic regression results for entrepreneurial characteristics and access to debt finance}

The results of the Pearson correlation for managerial competency are: education $(\mathrm{r}=0.747$, $\mathrm{p}$-value $=0.03)$, related experience $(\mathrm{r}=0.859, \mathrm{p}$-value $=0.01)$ and working experience $(\mathrm{r}=0.694, \mathrm{p}$-value $=0.02)$. The odd ratio for education is 4.17 with a p-value of 0.01 , the odd ratio for related experience is 5.03 with a p-value of 0.04 and the odd ratio for working experience is 3.97 with a p-value of 0.01 . The results of the Pearson correlation indicate that there is a significant positive relationship between managerial competency and access to debt finance by SMEs. The logistic regression also confirms these results.

The Pearson correlation results for networking are: between one and five years $(\mathrm{r}=0.271$, $\mathrm{p}$-value $=0.26)$, more than five years $(\mathrm{r}=0.329, \mathrm{p}$-value $=0.18)$, more than ten years $(\mathrm{r}=0.340, \mathrm{p}$-value $=0.37)$ and belonging to a trade association $(\mathrm{r}=0.388, \mathrm{p}$-value $=0.39)$. The odd ratio for firms older than five years is 2.83 with a $\mathrm{p}$-value of 0.38 , 
the odd ratio for firms older than ten years is 3.37 with a p-value of 0.21 and the odd ratio of belonging to a trade association is 1.49 with a p-value of 0.33 . The results of the Pearson correlation indicate that there is no significant relationship between networking and access to debt finance by SMEs. With firms between one and five years as the reference, the logistic regression also confirms these results. The results of the logistic regression indicate that SMEs that network are not significantly more likely to be successful in their credit application compared to SMEs that do not network. The Pearson correlation result for gender is 0.429 with a $\mathrm{p}$-value of 0.19 . The odd ratio for gender is 1.35 with a p-value of 0.21 . The results of the Pearson correlation indicate that there is no significant relationship between the gender of the SMEs owner/manager and access to debt finance.

\section{Managerial implications and recommendations}

For SMEs to survive and grow access to debt finance is critical. Collateral is an important determinant of credit access. This implies that SMEs without collateral will find it difficult to obtain debt finance from commercial banks. It is therefore necessary for owners of SMEs to have either business or personal assets that can be used as collateral when applying for credit facilities from commercial banks. Thus, owners of SMEs should be investment ready as Richard (2006) points out that "investors look out for very specific things when they assess requests for funding. Entrepreneurs must be made aware of the needs and concerns of particular types of investor". Training and communication on the requirements of banks and trade creditors can help to make SME owners to get investment ready and thus improve access to debt. Commercial banks can create awareness of their funding requirements especially the importance of collateral through advertisements and communication with trade associations. In addition, government and its agencies have, over the years, expended significant resources creating and implementing market interventions. It is vital that these interventions are effective and meet the needs of those they declare to support. It is therefore incumbent on Government and other stakeholders to ensure that these schemes, such as the Small Firm Loan Guarantee, are well publicised and made available to SMEs.

Lack of business information and managerial competencies are also important reasons why finances are not available from commercial banks. Therefore, to improve access to debt finance, there is the need for personal development by owners of the SMEs especially in the area of business and financial management skills through training. Government agencies such as SEDA and Development Corporations can organize training for SMEs. Awareness should be created for the training programmes through advertisements in local and national media. Furthermore, a "learning from peers" or mentorship can help to improve managerial competency. The high crime rate in South Africa must be reduced to improve the availability of debt from commercial banks and trade creditors. The best way to reduce crime and (and also corruption) is to make the legal system more efficient (especially the speed of court judgments) so that criminals are promptly arrested and punished. Government should work in partnership with organisations such as Business Against Crime South Africa and Business Unity South Africa. There is the need to create work opportunities for the vast number of the unemployed in South Africa. There is also a need for a well-publicized educational campaign against crime. More effective policing is needed, including better police visibility, area coverage and faster response times. SMEs should be encouraged to insure their businesses. Government can assist in subsidizing the cost of insurance.

\section{Limitations and areas for further research}

A significant limitation of this study is that it investigated mainly internal factors. External factors of lending were not investigated. Barbosa and Moraes (2004) find out that external factors such as the economic and legal environments can impact on the access to debt finance from commercial banks. In addition, the study focused only on debt finance from commercial banks. Furthermore, the study focused on the demand side of access to debt finance (perception of SMEs) and not the supply side (perception of commercial banks). A dyadic survey to examine the obstacles to credit as perceived by providers of funds (commercial banks) and SMEs could help to further confirm the findings of this study.

\section{References}

Abor, J. (2007). Industry Classification and the Capital Structure of Ghanaian SMEs. Studies in Economics and Finance, 24(3), 207-219.

Abor, J. (2008). Determinants of the Capital Structure of Ghanaian firms. Small Business Economics. [Online]. Available: http://www.aercafrica.org/documents/RP176.pdf (July 20, 2010)

Abor, J., \& Quartey. A. (2010). Issues in SME Development in Ghana and South Africa. International Research Journal of finance and Economics, 39(6), 215-228

Barbosa, E.G., \& Moraes, C.C. (2004). Determinants of the firm's capital structure: The case of the very small enterprises. [Online]. Available: http://econpa.wustl.edu.8089/eps/fin/papers 0302/0302001.pdf. (January 18, 2010).

Beck, T. (2007). Financing constraints of SMEs in developing countries: evidence, determinants and solutions. Journal of International Money and Finance, 31(2), 401-441.

Berger, A., \& Udell, G. (2006). A more conceptual framework for SME financing. Journal of Banking and 
Finance, 30(11), 2945-2966.

Berry, A., Von Blottnitz, M., Cassim, R., Kesper, A., Rajaratnam, B., \& Seventer, D.E. (2002). The economics of SMMES in South Africa. [Online] Available: http://www.tips.org.za/506.pdf. (August 15, 2010).

Bougheas, S., Mizen, P., \& Yalcin, C. (2005). Access to external finance: Theory and evidence on the impact of monetary policy and firm-specific characteristics. Journal of Banking \& Finance, 30(1), 199-227.

Burkart, M.C., \& Ellingsen, T. (2004). In-kind Finance: A Theory of Trade Credit. American Economic Review, 94(3), 569-590.

Cassar, G. (2004). The financing of business start-ups. Journal of Business Venturing, 19(2), 261-283.

Chandler, J. G. (2009). Marketing tactics of selected small firms in the East London CBD area. South Africa: University of South Africa.

Chidokufa, M. (2009). An investigation into the usage of insurance by SMEs in the Buffalo City Municipality. Unpublished Masters thesis, University of Fort Hare, South Afica.

Coco, G. (2000). On the use of collateral. Journal of Economic Surveys, 14(2), 191-214.

Coleman, S. (2000). The liability of newness and small firm access to debt: is there a link. Journal of Entrepreneurial Finance and Business Ventures, 9(2), 116-132.

Coleman, S., \& Cohn, R. (2000). Small firm use of financial leverage: Evidence from 1993 national survey of small business finance. Journal of Business Entrepreneurship, 12(3), 81-98.

Coulthard, M., \& Loos, J. (2007). Networking, the link in firm based entrepreneurial orientation (EO) performance model. [Online] Available: http://www.buseco.monash.edu.au/mgt/staff/coulthard.max.html. (July 20, 2010).

Demirguc-Kunt, A., Maksimovic, V., Beck, T., \& Laeven, L. (2006). The determinant of financing obstacles. International Journal of Money and Finance, 25, 932-952.

European Union. (2009). Enterprise and Industry. [Online] Available: http://ec.europa.eu/enterprise/index-eu.htm. (September 15, 2010).

FinMark Trust. (2006). Fin scope small business survey report. [Online] Available: http://www.finmarktrust.org.za (July 15, 2010).

Freel, M., Carter, S., Tagg, S., \& Mason, S. (2010). The latent demand for bank debt, characterising discouraged borrowers. Small Business Economics, 1(1), 1-16.

Frelinghaus, A., Mostert, B., \& Firer, C. (2005). Capital structure and the firm's life stage. South African Journal of Business Management, 36(4), 9-18.

Gilbert, B.A. (2008). New venture performance: does location matters? [Online] Available: http://74.125.77.132/search/q=cache.DIZnExwD91tmw.j.ftp/ftp.zew.de/pub (May 17, 2010).

Gitman, L.J. (2003). The Principles of Managerial Finance. New York: Pearson Education Inc.

Hall, G., Hutchinson, P., \& Michealas, N. (2000). Industry effect on the determinants of Unquoted SMEs Capital Structure. International Journal of the Economic of Business, 7(3) 297-312.

Herrington, M., \& Wood, E. (2003). Global Entrepreneurship Monitor, South African Report. [Online] Available: http://www.gbs.nct.ac.za/gbswebb/userfiles/gemsouthafrica2000pdf (May 15, 2010).

Hisrich, R.D., \& Drnovsek, M. (2002). Entrepreneurship and Small Business Research. Journal of Small Business and Enterprise Development, 9(2), 172-222.

Honhyan, Y. (2009). The Determinants of Capital Structure of the SMEs: An Empirical Study of Chinese listed Manufacturing Companies. [Online] Available: http://www.seiofbluemontain.com/upload/product/200911/2009.pdf (June 15, 2010).

Jensen, M.C., \& Meckling W.H. (1976). Theory of the firm: managerial behaviour, agency cost and ownership structure. Journal of financial Economics, 3(4), 305-360.

Kitindi, E.G., Magembe, B.A.S., \& Sethibe, A. (2007). Lending decision making and financial information: the usefulness of corporate annual reports to lender in Botswana. International Journal of Applied Economics and Finance, 1(2), 55-60.

Klapper, L., Laeven, L., \& Rajan, R. (2010). Entry regulation as a barrier to entrepreneurship. Journal of Financial Economics, 82(3), 591-623.

Korkeamaki, T.P., \& Rutherford, M.W. (2006). Industry effects and banking relationship is determinant of Small firm Capital Structure Decisions. [Online] Available: http://www.jepson.gonzaga.edu/timok/sme\%20cap\%20structure.pdf (January 10, 2010).

Kraus, A., \& Litzenberger, R.H. (1973). A state-preference model of optimal financial leverage. Journal of Finance, 9(1), 911-922. 
Le, T.B.N., Venkatesh, S., \& Nguyen, V.T. (2006). Getting bank financing: study of Vietnamese private firms. Asia Pacific Journal of Management, 23(2), 209-227.

Majed, G.FM., Alsharayri, A., \& Dandan, M.M. (2010). Impact of firm characteristic on Determining Financial Structure on the Insurance Sector Firms in Jordan. Journal of Social Sciences, 6(2), 282-286.

Martin, G., \& Staines, H. (2008). Managerial competencies in small firm. [Online] Available: http://www.emraldinsight.com/insight/viewcontentitem.do?contenttype (July 17, 2010).

Mijid, N. (2009). Gender, race and credit rationing of small businesses evidence from the 2003 survey of small business finance. [Online] Available: http://www.kauffman.org/research-and-policy/kdfp/fellows.aspx (October $16,2010)$.

Modigliani, F., \& Miller, M.H. (1958). The cost of capital, corporation finance and the theory of investment. American Economic Review, 48(3), 261-295

Modigliani, F., \& Miller, M.H. (1963). Corporate income taxes and the cost of capital: A correction. American Economic Review, 53(3), 433-444.

Myers, S.C. (1984). Capital structure puzzle. Journal of Finance, 39(1), 575-592.

Ngoc, T.B., Le, T., \& Nguyen, T.B. (2009). The impact of networking on bank financing: The case of small and medium enterprises in Vietnam. Entrepreneurship Theory and Practice, 33(4), 867-887.

Owualah, S.L. (2002). SMEs borrowing constraints and banking relationship in Japan. Japan and the World Economy, 14(1), 87-100.

Pretorius, M., \& Shaw, G. (2004). Business plan in bank-decision making when financing new ventures in South Africa. South African Journal of Economics and Management Science, 7(2), 221-242.

Richard, D. (2006). Equity gap? There is no such thing. [Online] Available: http://www.growingbusiness.co.uk (August 17, 2010).

Sarapaivanich, N., \& Kotey, B. (2006). The effect of financial information quality on ability to access external finance and performance of SMEs in Thailand. Journal of Enterprising Culture, 14(3), 219-239.

Scott, D.F. (1972). Evidence on the importance of financial structure. Journal on Financial Management, 1(3), 45-60.

Shane, S. (2008). The importance of angel investing in financing the growth of entrepreneurial ventures. [Online] Available: htt://www.sba.gov/adw/research/banking.html (January 15, 2010).

Smith, R.L., \& Smith, J.K. (2004). Entrepreneurial Finance. $2^{\text {nd }}$ Edition. New York:John Wiley and Sons.

Smorfitt, R. (2009). SMEs in South Africa: why is finance difficult to access? [Online] Available: http://innoveur.blogspot.com (January 10, 2010).

Sorooshian, S., Norzima, Z., Yusuf, I., \& Rosnah, Y. (2010). Structural Modeling of Entrepreneurships effectiveness. World applied Sciences Journal, 10(8), 923-929.

South African Police Service (SAPS). (2009). Crime statistics. [Online] Available: http://www.saps.org (September 14, 2010).

South African Presidency. (2008). The impact of crime on small business in South Africa. [Online] Available: http://www.info.gov.za/view/downloadfileaction/pdf (September 14, 2010).

STARTS Corporation. (2010). Calculation of sample size software by Raosoft. [Online] Available: http://www.raosoft.com/samplesise.html (November 10, 2010).

Statistics South Africa. (2010). Quarterly labour force survey. [Online] Available: http://www.statssa.gov.za/publication/find publication asp (January 10, 2010).

Stiglitz, J., \& Weiss, A. (1981). Credit rationing in markets with imperfect information. American Economic Review, 71, 393-410.

United Nations Human Settlement Programme. (2002). Murder rate. [Online] Available: http://www.unhabitat.org.yu/about-usloverview.htm (August 10, 2010)

Watson, J., Newby. R., and Mahuka, A. (2009). Gender and the SME finance gap. International Journal of Gender and Entrepreneurship, 1(1):42-56 
Table 1. Results of Correlation

\begin{tabular}{|l|l|l|}
\hline Item & \multicolumn{2}{|l|}{ Access to debt finance } \\
\hline & $\mathrm{R}$ & P-value \\
\hline Collateral & & \\
\hline Ownership of personal property & 0.957 & 0.01 \\
\hline Ownership of business building & 0.824 & 0.03 \\
\hline Insurance & 0.771 & 0.02 \\
\hline Managerial competency & & \\
\hline Education & 0.747 & 0.03 \\
\hline Related experience & 0.859 & 0.01 \\
\hline Working experience & 0.694 & 0.02 \\
\hline Business information & & \\
\hline Availability of business plan & 0.834 & 0.04 \\
\hline Keeping of financial information & 0.627 & 0.01 \\
\hline Networking & & \\
\hline Between one and five years & 0.271 & 0.26 \\
\hline More than five years & 0.329 & 0.18 \\
\hline More than ten years & 0.340 & 0.37 \\
\hline Belong to a professional association & 0.388 & 0.39 \\
\hline Age of the firm & & \\
\hline $1-4$ years & 0.293 & 0.12 \\
\hline $5-9$ years & 0.557 & 0.01 \\
\hline $10-14$ years & 0.595 & 0.03 \\
\hline 15 and above & 0.681 & 0.02 \\
\hline Size of the firm (no. of employees) & & \\
\hline $1-49$ & 0.252 & 0.29 \\
\hline $50-99$ & 0.497 & 0.02 \\
\hline $100-149$ & 0.643 & 0.04 \\
\hline $150-200$ & 0.776 & 0.01 \\
\hline Demographics & & \\
\hline Gender & 0.429 & 0.19 \\
\hline Legal status of the firm & 0.673 & 0.04 \\
\hline Business line & 0.197 & 0.37 \\
\hline Age of the owner & & \\
\hline Below 20 & 0.147 & 0.13 \\
\hline $21-30$ & 0.216 & 0.31 \\
\hline $31-40$ & 0.305 & 0.25 \\
\hline $41-50$ & 0.364 & 0.15 \\
\hline $51-60$ & 0.407 & 0.27 \\
\hline Location of the firm & & \\
\hline Urban & 0.764 & 0.03 \\
\hline Rural & 0.217 & 0.29 \\
\hline & & \\
\hline & & \\
\hline & & \\
\hline & & \\
\hline
\end{tabular}

Sig. 0.05 
Table 2. Results of logistic regression

\begin{tabular}{|c|c|c|c|}
\hline Variable & Odd ratio & Confidence interval (95\%) & P-value \\
\hline \multicolumn{4}{|l|}{ Collateral } \\
\hline Personal property & 7.14 & $3.00-9.99$ & 0.03 \\
\hline Business property & 6.29 & $3.00-9.50$ & 0.01 \\
\hline Insurance & 6.02 & $5.50-8.25$ & 0.04 \\
\hline \multicolumn{4}{|l|}{ Managerial competency } \\
\hline Education & 4.17 & $2.34-8.22$ & 0.01 \\
\hline Working experience & 3.97 & $1.50-5.59$ & 0.01 \\
\hline Related experience & 5.03 & $2.55-8.51$ & 0.04 \\
\hline \multicolumn{4}{|l|}{ Business information } \\
\hline Business plan & 6.81 & $3.10-10.00$ & 0.01 \\
\hline Financial information & 6.11 & $3.27-9.91$ & 0.03 \\
\hline \multicolumn{4}{|l|}{ Networking and relationship } \\
\hline Between one and five years (reference) & 1.00 & & \\
\hline More than five years & 2.83 & $2.16-4.63$ & 0.38 \\
\hline More than ten years & 3.37 & $2.59-6.94$ & 0.21 \\
\hline Belonging to a professional association & 1.49 & $0.50-1.59$ & 0.33 \\
\hline \multicolumn{4}{|l|}{ Age of the firm } \\
\hline 1-4 years (reference) & 1.00 & & \\
\hline $5-9$ years & 5.36 & $3.41-7.98$ & 0.04 \\
\hline 10-14 years & 5.88 & $3.55-7.90$ & 0.02 \\
\hline 15 and above & 6.41 & $3.62-8.11$ & 0.02 \\
\hline \multicolumn{4}{|l|}{ Size of the firm (no. of employees) } \\
\hline $1-49$ (reference) & 1.00 & & \\
\hline $50-99$ & 3.30 & $2.82-6-49$ & 0.03 \\
\hline $100-149$ & 4.42 & $3.14-6.53$ & 0.01 \\
\hline $150-200$ & 4.59 & $3.14-7.20$ & 0.01 \\
\hline \multicolumn{4}{|l|}{ Demographic } \\
\hline Gender & 1.35 & $0.65-2.75$ & 0.21 \\
\hline Legal status of the firm & 5.72 & $2.25-7.1$ & 0.04 \\
\hline Business line & 2.71 & $2.09-6.59$ & 0.23 \\
\hline \multicolumn{4}{|l|}{ Age of the owner } \\
\hline Below 20 (reference) & 1.00 & & \\
\hline $21-30$ & 2.57 & $2.21-3.93$ & 0.23 \\
\hline $31-40$ & 2.63 & $2.40-3.96$ & 0.19 \\
\hline $41-50$ & 2.94 & $2.57-4.01$ & 0.23 \\
\hline $51-60$ & 3.19 & $2.66-4.12$ & 0.26 \\
\hline \multicolumn{4}{|l|}{ Location } \\
\hline Urban & 6.81 & $3.02-7.41$ & 0.02 \\
\hline Rural & 1.26 & $2.12-3.07$ & 0.34 \\
\hline
\end{tabular}

Sig. 0.05 